\title{
EDUWISATA BAHARI BERBASIS PEMBERDAYAAN MASYARAKAT DALAM PENGEMBANGAN TAMAN LAUT OLELE, KAB. BONE BOLANGO, PROVINSI GORONTALO
}

\author{
Atika Marzaman \\ Ilmu Pemerintahan, Universitas Gorontalo \\ tika.marzaman@gmail.com \\ Ayub Usman Rasyid \\ Ilmu Manajemen, Universitas Gorontalo \\ ayub_lpmunigo@yahoo.com
}

\begin{abstract}
This study seeks to propose a plan for sustainable development in the management of the Olele Marine Park area as an educational-tourism area based on community empowerment. Qualitative research methods with data collection techniques through surveys, interviews and focus group discussions. The results of the study explain the potential for the development of marine tourism in Olele Marine Park, Bone Bolango Regency. Olele as one local sea park has a very large tourism potential if viewed from its diversity of marine life. As for the obstacles are the low quality of the management of the tourism sector management both in terms of infrastructure and human resource capacity. In addition there has been no synchronization between the roles of the government, the private sector and the citizens of Olele Village, so that the development of a sustainable tourism sector cannot yet be achieved. Olele Beach, in fact, does not provide large economic benefits to the residents of Olele Village. The competition of tourism service providers has made Olele Village residents unable to reap profits and advantages from tourism sector.
\end{abstract}

Keywords: marine tourism, Olele marine park, community empowerment.

\section{Pendahuluan}

Wilayah pesisir semakin menjadi pembahasan dengan melihat urgensitasnya bagi kehidupan manusia. Pengembangan wilayah pesisir menjadi wilayah yang bernilai ekonomis tentunya perlu untuk mendapat perhatian baik oleh masyarakat pesisir terutama oleh pemerintah daerah setempat. Tidak dapat dipungkiri pula bahwa wilayah pesisir memiliki nilai ekonomi tinggi akan tetapi terus terancam 
keberlanjutannya. Dengan potensi yang unik dan bernilai ekonomi tadi maka wilayah pesisir dihadapkan pada ancaman yang tinggi pula, maka hendaknya wilayah pesisir ditangani secara khusus agar wilayah ini dapat dikelola secara berkelanjutan.

Wilayah Indonesia yang didominasi oleh perairan tidak secara langsung menjadikan wilayah pesisir sebagai prioritas pembangunan. Wilayah pesisir khususnya di Provinsi Gorontalo, belum mendapat perhatian yang baik dan sebagian besar masih dikelola secara tradisional (Kamuli 2018). Masih rendahnya kesadaran terhadap pelestarian lingkungan sehingga dampak kerusakan akibat kehadiran para pengunjung objek wisata juga masih menjadi masalah. Disamping itu dampak secara ekonomi dari pengembangan destinasi wisata pada dasarnya masih sangat kecil bagi masyarakat setempat. Pada dasarnya destinasi wisata memiliki dampak ekonomi langsung yang langsung diterima pada suatu destinasi wisata tersebut yang bersumber dari pengeluaran wisatawan pada saat melakukan aktivitas wisata. Kepada masyarakat yang tidak melakukan usaha dan tidak ada aktivitas di destinasi tersebut, tidak mendapatkan apapun meskipun masyarakat tersebut merupakan penduduk lokal (Agfianto 2019).

Untuk itu penting merumuskan suatu model pengelolaan sektor wisata yang berkelanjutan. Eduwisata adalah kemasan wisata yang memadukan konsep wisata yang dipadukan dengan nilai-nilai pendidikan. Kemasan yang disajikan pun sangat sederhana tetapi memiliki bobot edukasi yang penting, seperti berwisata di desadesa adat atau penjelasan mengenai pelestarian ekosistem laut. Pengembangan eduwisata juga akan sejalan dengan proses pemberdayaan masyarakat. Dimana dengan dibukanya suatu daerah sebagai suatu kawasan eduwisata secara otomatis masyarakat yang ada didalamnya akan lebih diberdayakan dengan programprogram pengembangan daerah wisata. Di sisi lain kearifan lokal masyarakat juga akan lebih terjaga bahkan lebih dari itu akan budaya masyarakat dapat 
Eduwisata Bahari Berbasis Pemberdayaan Masyarakat dalam Pengembangan Taman Laut Olele...

disosialisasikan secara lebih luas. Kearifan lokal sebagai aset pariwisata terbukti telah menyukseskan bebeberapa desa wisata (Suyanto et al. 2018).

Konsep eduwisata berbasis masyarakat diprioritaskan untuk memberikan ruang yang seluas-luasnya bagi masyarakat wilayah objek wisata untuk melakukan perencanaan dan pengelolaan usaha eduwisata. Hal ini dikarenakan masyarakatlah yang mengetahui lebih banyak mengenai potensi hingga daya tarik wisata yang dimiliki oleh suatu lokasi wisata. Untuk itu menjadi suatu keharusan adanya pelibatan aktif elemen masyarakat. Hal ini tentunya akan memberikan dampak positif dengan terciptanya kesempatan kerja bagi masyarakat sekitar (Savitri dan Utami 2018). Pengembangan konsep ini juga akan mampu mencegah adanya upaya pengrusakan terhadap objek maupun sarana wisata.

Sebagai salah satu sektor wisata bahari yang terletak di Desa Olele, Kecamatan Kabila, Kabupaten Bone Bolango, Taman Laut Olele masih menjadi hidden paradise. Sebagian besar daerahnya memiliki laut dan hanya sebagian kecil dari daratan yang digunakan untuk pemukiman. Dari sisi pariwisata Taman Laut Olele memiliki sumber daya wisata yang bernilai tinggi. Taman Laut Olele dikenal dengan biota laut dan terumbu karang yang masih sangat terjaga keasliannya. Posisi yang berada di Teluk Tomini menjadikan Pantai Olele pantai yang landai dengan keindahan pantai dan kekayaan bawah lautnya (Mongabay, 2019).

Pengamatan terhadap Taman Laut Olele, sebelumnya telah dilakukan oleh Beby Sintia Dewi Banteng pada tahun 2013, dengan judul Pengelolaan Kawasan Pesisir Berbasis Masyarakat Di Taman Konservasi Laut Olele Kecamatan Kabila Bone Kabupaten Bone Bolango Provinsi Gorontalo. Hasil pengamatan tersebut menjelaskan bahwa Taman Konservasi Olele hingga tahun 2013 masih berpotensi di bidang pendidikan, penelitian, pariwisata dan bioteknologi kelautan. Survei lapangan tahun 2010-2012 dan data sekunder menunjukkan terdapat ekosistem 
terumbu karang dalam kondisi cukup baik dengan keanekaragaman biota dalam kondisi cukup tinggi (Benteng 2013).

Terkait aspek pengembangan pariwisata pengetahuan dan ketrampilan masyarakat di bidang pariwisata dalam usaha memanfaatkan sumberdaya alam masih kurang. Secara umum kedala yang dihadapi dalam pengembangan kawasan Olele adalah 1). Keterbatasan sumber daya manusia. Masyarakat pesisir Olele yang menguasai ilmu pengetahuan serta terlatih dalam perencanaan dan pengelolaan pemanfataan wilayah pesisir dan laut terbatas. 2) Persepsi sebagian masyarakat kurang tepat/salah tentang lingkungan pesisir (wilayah pesisir masih dianggap sebagai daerah akhir tempat pembuangan sampah). 3) Lemahnya aspek hukum dan sistem pendampingan kelembagaan di tingkat komunitas. 4) Kelembagaan. Sumber daya manusia (SDM) pengelola masih terbatas pada kelompok pengelola saja dan amatir (belum profesional). 5) Pengelolaan KKLD belum berbasis masyarakat. Keadaan ini diakibatkan oleh pengelolaan tidak berkolaborasi antara masyarakat dengan berbagai instansi terkait/pemerintah dan pihak swasta (Benteng 2013).

Sejalan dengan pengamatan sebelumnya, artikel ini menjelaskan mengenai konsep eduwisata sebagai alternatif pengembangan pariwisata bahari dalam rangka mengembangkan sektor pariwisata di Taman Laut Olele. Secara garis besar permasalahan yang seringkali muncul dalam pengelolaan destinasi wisata adalah, kesenjangan ekonomi, keterbatasan sumber daya dan kerusakan lingkungan. Untuk itu konsep yang coba dikaji secara mendalam adalah konsep eduwisata bahari dengan berbasis pada pemberdayaan masyarakat. Konsep ini dikembangkan dengan melibatkan aspek edukasi, konservasi dan pengembangan ekonomi lokal dalam suatu strategi pengembangan yang berkelanjutan. Oleh karena itu pembangunan secara terpadu dan berkelanjutan dengan pelibatan penuh masyarakat penting untuk dilakukan. 
Eduwisata Bahari Berbasis Pemberdayaan Masyarakat dalam Pengembangan Taman Laut Olele...

\section{Kerangka Pikir}

Studi tentang kepariwisataan bahari telah banyak berkembang seiring dengan semakin besarnya manfaat yang dirasakan dalam lintas sektor, terutama dalam sektor ekonomi. Hall menyatakan bahwa konsep pariwisata pesisir (coastal tourism) adalah hal - hal yang terkait dengan kegiatan wisata, hal - hal yang menyenangkan dan aktivitas rekreasi yang dilakukan di wilayah pesisir dan perairannya. Sementara itu, pariwisata bahari (marine tourism) sebagai aktivitas rekreasi yang meliputi perjalanan dari satu tempat ke tempat lain dan fokus pada lingkungan pesisir (Hall 2017).

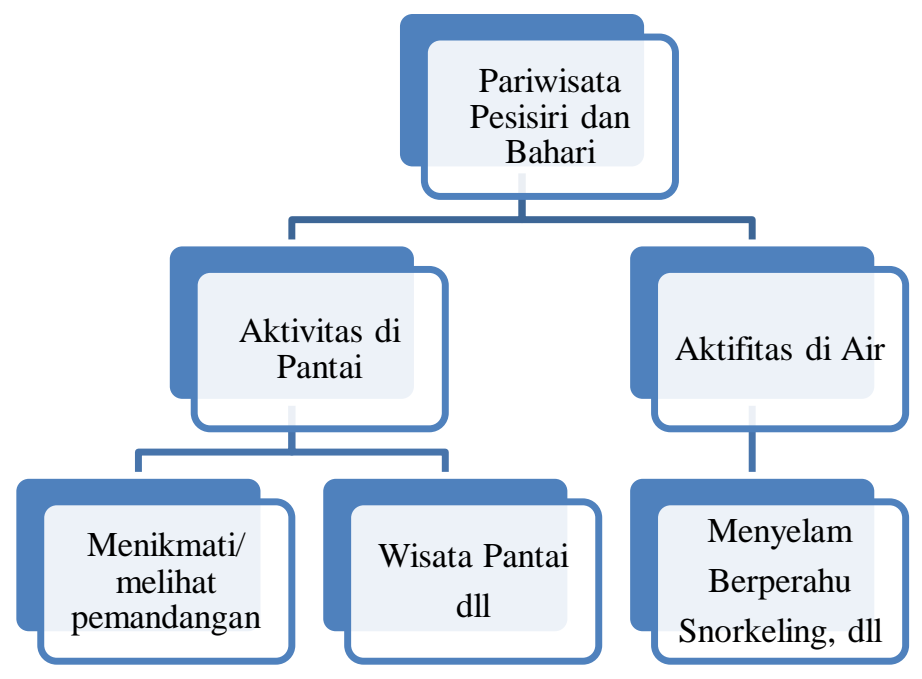

Gambar 1: Kerangka Pariwisata Pesisir dan Bahari (Hall 2017)

Pada dasarnya aktifitas wisata bahari tidak dapat dipisahkan dari potensi yang dimiliki oleh suatu wilayah dan aktifitas masyarakat yang ada didalamnya. Secara lebih spesifik diperlukan penerapan konsep eduwisata dengan berbasis pada pemberdayaan masyarakat. Secara sederhana konsep yang ditawarkan oleh Eduwisata adalah menggabungkan antara layanan wisata pada umunya namun selipi dengan berbagai macam nilai pendidikan praktis sesuai dengan tema yang diambil (Savitri dan Utami 2018). Konsep pengembangan wisata yang menghargai kaidah-kaidah alam dengan melaksanakan program pembangunan dan pelestarian secara terpadu antara upaya konservasi sumberdaya alam yang dilakukan, dengan 
melaksanakan program pembangunan yang memperhatikan kualitas daya dukung lingkungan dan ramah lingkungan. Melalui konsep eduwisata para wisatawan nantinya tidak hanya akan sekedar berwisata melainkan disuguhkan rangkaian program edukasi bahari seperti pengetahuan tentang konservasi mangrove, keanekaragaman biota laut hingga pemanfataan sumber daya bahari menjadi produk yang bernilai ekonomi.

Konsep eduwisata bahari hadir sebagai salah satu alternatif pengembangan pariwisata maritim yang berbasis kearifan lokal sekaligus sebagai sarana pemberdayaan masyarakat. Disamping itu konsep eduwisata dianggap sebagai jalan keluar masalah perekonomian masyarakat yang masih sangat sedikit tersentuh oleh modernisasi. Dengan konsep eduwisata maka masyarakat mampu mengembangkan potensi lokal tanpa menghilangkan kearifan budaya. Konsep eduwisata nantinya akan menawarkan keaslian baik dari segi sosial budaya, adat istiadat, keseharian, arsitektur tradisional, struktur tata ruang desa yang disajikan dalam suatu suatu bentuk integrasi komponen pariwisata antara lain seperti atraksi, akomodasi dan fasilitas pendukung.

Tujuan pariwisata dapat tercapai dengan efektif jika pembangunan dilakukan dengan perencanaan yang baik dan terintegrasi dengan pengembangan daerah secara keseluruhan. Untuk itu dalam konsep eduwisata mengutamakan pemberdayaan masyarakat dalam penyelenggaraannya. Wihasta menjelaskan bahwa pendekatan pembangunan pariwisata yang menempatkan masyarakat sebagai bagian yang tidak terpisahkan dari produk wisata dan pemahaman bahwa produk wisata merupakan proses rekayasa sosial masyarakat merupakan esensi dari pembangunan yang berbasis pada komunitas atau masyarakat (community based development). Asumsi ini kemudian memunculkan pendapat bahwa pembangunan pariwisata pada kenyataannya tidak dapat dipisahkan dari masyarakat itu sendiri (Sidiq dan Resnawaty 2017). 
Pariwisata berbasis masyarakat sebagai sebuah pendekatan yang melibatkan dan meletakkan masyarakat sebagai pelaku penting dalam konteks paradigma pembangunan yang berkelanjutan (sustainable development paradigma. Pariwisata berbasis masyarakat merupakan peluang untuk menggerakkan segenap potensi dan dinamika masyarakat, guna mengimbangi peran pelaku usaha pariwisata skala besar. Pariwisata berbasis masyarakat tidak berarti merupakan upaya kecil dan lokal semata, tetapi perlu diletakkan dalam konteks kerjasama masyarakat secara global (Sastrayuda 2010). Dengan berkembanganya pariwisata berbasis masyarakat, masyarakat lokal akan memperoleh pendapatan tambahan dan ketergantungan masyarakat terhadap sumber daya alam akan berkurang. Salah satu harapan pariwisata berbasis masyarakat adalah agar pembagian keuntungan dari usaha pariwisata lebih banyak diterima langsung oleh masyarakat.

Pengembangan desa wisata berbasis masyarakat merupakan pendekatan yang menawarkan peran yang lebih kepada masyarakat untuk terlibat dalam keseluruhan proses pengembangan desa wisata. Pengembangan desa wisata berbasis masyarakat juga mengakui eksistensi masyarakat sebagai bagian integral dari desa, sehingga proses yang dilaksanakan ditujukan sepenuhnya untuk memberdayakan masyarakat dan memberikan keuntungan yang sebesar-besarnya kepada masyarakat (Herdiana n.d.).

Proses integrasi konsep edukasi wisata dengan pelibatan penuh dari masyarakat menjadi fokus utama dalam implementasi eduwisata. Di satu sisi pengembangan destinasi wisata dalam hal ini wisata bahari di Taman Laut Olele akan tetap memberikan keuntungan yang sebesar-besarnya bagi masyarakat setempat yang terlibat penuh dalam pengelolaannya. Di sisi lain, penyelenggaraan wisata akan memberikan pendidikan bagi pengunjung terkait dengan pentingnya pelestarian lingkungan dan ekosisitem. 


\section{Metode Penelitian}

Penelitian dilakukan di Taman Laut Olele Kabupaten Bone Bolango, Provinsi Gorontalo. Dengan menggunakan pendekatan penelitian kualitatif penelusuran data meliputi data primer dan sekunder. Data primer diperoleh dari: masyarakat setempat, LSM, pelaku usaha, Dinas Perikanan dan Kelautan, Dinas Perindustrian dan Perdagangan, Dinas Pariwisata, dan Dinas/ Badan terkait lainnya di Kabupaten Bone Bolango. Sementara data sekunder diperoleh dari dokumen berupa laporan dari berbagai kegiatan pengembangan wisata bahari yang pernah dilaksanakan.

Pengumpulan data dilakukan melalui: 1. Survei dilakukan untuk mengetahui potensi pariwisata bahari sekaligus mengindentifikasi permasalahan yang dihadapi dalam aktivitas pengembangannya; 2. Wawancara dilakukan untuk mendalami aktivitas masyarakat dan potensi pengembangan eduwisata bahari; 3. Focus Group Discussion (FGD), merupakan diskusi yang dilakukan secara sistematis untuk merumuskan suatu metode pengembangan eduwisata bahari berbasis pemberdayaan masyarakat yang melibatkan berbagai unsur, seperti: Dinas Pariwisata, Dinas Perikanan dan Kelautan dan pihak terkait lainnya.

\section{Hasil dan Pembahasan}

\section{Potensi Taman Laut Olele}

Taman Laut Olele merupakan salah satu destinasi wisata unggulan di Provinsi Gorontalo. Hal ini dikarenakan Taman Laut Olele memiliki keanekaragaman biota laut yang mampu menarik wisatawan. Keunikan karang dan biota laut menjadikan Taman Laut Olele ramai dikunjungi oleh wisatawan baik dosemstik maupun mancanegara. 
Eduwisata Bahari Berbasis Pemberdayaan Masyarakat dalam Pengembangan Taman Laut Olele...

Tabel 1 : Data Kunjungan Wisatawan Nusantara dan Mancanegara Di Objek Wisata Sekabupaten Bone Bolango Tahun 2018

\begin{tabular}{|c|c|c|c|c|c|}
\hline \multirow{2}{*}{ No } & \multirow{2}{*}{ Lokasi obyek wisata } & \multirow{2}{*}{ Obyek wisata } & \multicolumn{2}{|l|}{ Jumlah } & \multirow{2}{*}{ Jumlah total } \\
\hline & & & Wisnus & Wisman & \\
\hline 1 & Kecamatan Bone & Air Terjun Taludaa & 2986 & 0 & 2986 \\
\hline 2 & Kecamatan Bulawa & Pantai Pinomontiga & 1106 & 0 & 1106 \\
\hline \multirow[t]{5}{*}{3} & $\begin{array}{l}\text { Kecamatan Kabila } \\
\text { Bone }\end{array}$ & Pantai Botutonuo & 45622 & 230 & 45852 \\
\hline & & Taman Laut Olele & 11714 & 1631 & 13345 \\
\hline & & Pantai Molotabu & 6176 & 0 & 6176 \\
\hline & & Pantai Bindalahe & 3103 & 3 & 3106 \\
\hline & & Botubarani/hiu paus & 16847 & 1510 & 18357 \\
\hline 4 & Kecamatan Tapa & Pemandian Meranti & 27536 & 0 & 27536 \\
\hline 5 & $\begin{array}{l}\text { Kecamatan Bulango } \\
\text { Utara }\end{array}$ & River Tubing & 1556 & 0 & 1556 \\
\hline 6 & Kecamatan Suwawa & Danau Perintis & 7493 & 0 & 7493 \\
\hline 7 & $\begin{array}{l}\text { Kecamatan Suwawa } \\
\text { Tengah }\end{array}$ & Pemandian Lombongo & 55008 & 301 & 55309 \\
\hline 8 & $\begin{array}{l}\text { Kecamatan Suwawa } \\
\text { Timur }\end{array}$ & Hungayono & 1659 & 59 & 1718 \\
\hline & JUMLAH & & 180806 & 3734 & 184540 \\
\hline
\end{tabular}

Sumber : BAPPEDA Bone Bolango 
Tabel 1 menggambarkan jumlah wisatawan domestik dan asing yang berkunjung di Kabupaten Bone Bolango. Dari tabel tersebut terlihat bahwa jumlah pengunjung di kawasan Bone Bolango masih sedikit jika dibandingkan dengan wilayah lainnya. Setelah dikonfirmasi kepada pemerintah daerah menyatakan bahwa sektor pariwisata sebenarnya menjadi prioritas pemerintah daerah. Akan tetapi memang diperlukan strategi yang tepat dan pembiayaan yang besar dalam pengembangan sektor wisata. Adapun persentasi kunjungan tersebut dijelaskan pada grafik di bawah ini.

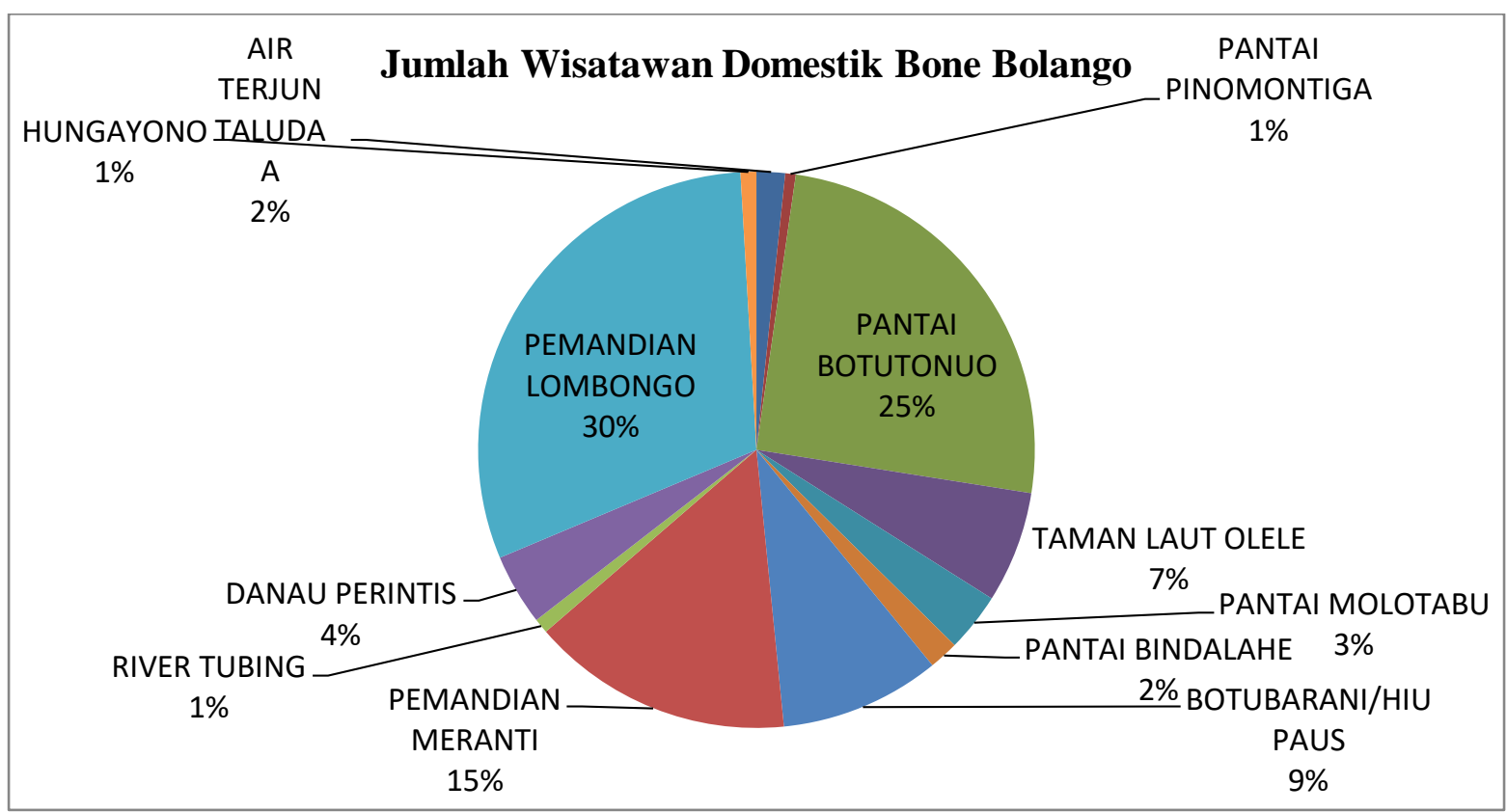

Gambar 2. Wisatawan Domestik Bone Bolango 2018

Sumber : Olahan data peneliti (2018) 


\section{Jumlah Wisatawan Mancanegara Bone Bolango}

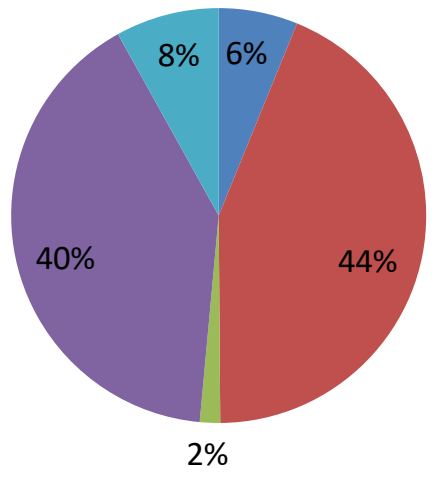

PANTAI BOTUTONUO

- TAMAN LAUT OLELE

HUNGAYONO

BOTUBARANI/HIU PAUS

- PEMANDIAN LOMBONGO

Gambar 3. Wisatawan Mancanegara Bone Bolango 2018

Sumber : Olahan data peneliti (2018)

Grafik 1 menujukkan bahwa Wisata Taman Laut Olele hanya dikunjungi oleh sekitar 7\% dari jumlah wisatawan domestik Kabupaten Bone Bolango pada tahun 2018. Sementara itu Grafik 2 menujukkan bahwa Taman Laut Olele menjadi urutan pertama sebagai objek wisata dengan wisatawan asing dengan persentase $44 \%$ dari jumlah pengunjung asing di Kabupaten Bone Bolango tahun 2018. Hal ini tentunya mengindikasikan bahwa Taman Laut Olele lebih menarik bagi wisatawan asing. Berdasarkan hasil wawancara dengan Dinas Pariwisata Kabupaten Bone Bolango, tingginya kunjungan wisatawan asing di Taman Laut Olele dikarenakan keanekaragaman karang dan biota laut. Disisi lain rendahnya kunjungan domestik dikarenakan kurangnya ketertarikan eksplorasi bawah laut, dimana kegiatan menyelam belum dikenal luas. Pada umumnya wisatawan domestik lebih menyukai pantai dengan pasir.

Hal ini tentunya menjadi potensi yang sangat besar dan dapat dikembangkan lebih lanjut. Pemerintah daerah sendiri telah melakukan upaya pengembangan kawasan wisata, dimana Taman Laut Olele masuk dalam prioritas. Pemerintah daerah menargetkan Penyusunan Rencana Induk Pengembangan Obyek Wisata (RIPOW) untuk obyek wisata : Lombongo, obyek wisata bawah laut Olele, obyek 
wisata Taman Laut Botutunuo, obyek wisata Taman Laut Molutabu, dan obyek wisata Puncak Meranti. Di samping itu pemerintah memprioritaskan untuk membuka dan meningkatkan kualitas jalan akses dari jalan raya menuju titik lokasi obyek wisata pada 5 target obyek wisata dari 6 obyek wisata yaitu (Wisata Taman Laut Botutunuo, wisata Taman Laut Molutabu, wisata alam Puncak Meranti, obyek wisata Lombongo, dan obyek wisata bawah laut Olele) (RIPDA 2015).

Adapun yang menjadi kekhawatiran adalah terkait dengan kelestarian hayati yang mengalami kerusakan akibat pemanfaataan yang tidak bertanggung jawab. Dalam hal ini pengembangan konsep eduwisata sendiri sebagai solusi untuk mengembangkan potensi wisata dengan tetap menjaga kelestarian lingkungan dengan memberikan pengetahuan kepada masyarakat. Eduwisata merupakan konsep wisata yang menanamkan nilai - nilai edukasi kepada masyarakat terutama wisatawan yang datang berkunjung. Hal ini tentunya penting dengan melihat fakta bahwa lokasi wisata seringkali rusak akibat aktifitas pengunjung yang tidak bertanggung jawab. Melalui konsep ini, wisatawan yang mengunjungi destinasi wisata akan ditemani oleh pemandu yang menjelaskan mengenai keanekaragaman hayati dan upaya-upaya pelestarian serta tindakan-tindakan yang dapat merusak.

Sebagai salah satu wilayah konservasi laut, Taman Laut Olele tentunya harus menerapkan aturan yang ketat terhadap setiap pengunjung. Di sisi lain pengunjung harus diberikan pemahaman mengenai pentingnya pelestarian terumbu karang, tidak hanya untuk tujuan wisata tetapi untuk kelestarian ekosistem laut secara lebih luas. Pemerintah desa dan pemerintah daerah pada umumnya telah melakukan upaya pelestarian kawasan Taman Laut Olele. Hal ini terimplementasikan dengan dibuatnya Peraturan desa No. 01/PERDES/D-OL/KL-BB/XI-2006 tentang Koneservasi Daerah Perlindungan Laut Berbasis Masyarakat. Peraturan desa ini menjelaskan mengenai keterlibatan masyarakat dalam pengelolaan sumber daya bahari yang terdapat di Taman Laut Olele. Perdes ini juga menjelaskan kewajiban masyarakat untuk menjaga kelestarian lingkungan di pesisir Olele. Perdes ini 
Eduwisata Bahari Berbasis Pemberdayaan Masyarakat dalam Pengembangan Taman Laut Olele...

mengatur zonasi pemanfaatan potensi bahari. Di samping itu perdes juga menetapkan sanksi bagi pihak-pihak yang melakukan pengrusakan terhadap ekosistem. Selanjutnya dibuat Surat Keputusan Bupati Bone Bolango, No. 165 Tahun 2006. Tentang Penetapan Kawasan Konservasi Laut Daerah di Desa Olele Kecamatan Kabila Bone Kabupaten Bone Bolango. Melalui SK ini maka pemerintah melakukan upaya berkelanjutan dalam pengelolaan kawasan konservasi Bone Bolango.

Desa Olele sendiri juga telah membentuk kelompok pengawas yang terdiri masyarakat Desa Olele sendiri. Tugas dan fungsi dari kelompok ini adalah untuk melakukan pengawasan terhadap segala aktivitas bawah laut yang dilakukan di Taman Laut Olele. Hal ini dilakukan sebagai upaya preventif dimana pernah terjadi sekelompok orang meminta izin untuk menyelam akan tetapi melakukan penangkapan ikan dan mengambil karang secara ilegal. Dengan adanya kelompok ini maka peluang terjadinya tindakan pengrusakan terumbu karang dan ikan-ikan di Taman Laut Olele dapat lebih mudah dihindari.

Tingginya kesadaran masyarakat Desa Olele terhadap kelestarian lingkungan tentunya menjadi modal besar dalam pengembangan sekor wisata yang berelanjutan. Diakui oleh Sekretaris Desa Olele bahwa pemuda desa pada dasarnya sudah berpartipasi aktif baik dalam hal penyelenggaraan wisata maupun dalam pelestarian terumbu karang. Pemuda desa juga aktif melakukan pembersihan bawah laut dan pantai dengan memusnahkan bulu babi yang dianggap dapat merusak terumbu karang. Dalam hal ini dapat kita lihat bahwa kesadaran masyarakat terkait dengan kelestarian kawasan konservasi laut telah dimiliki.

Berdasarkan hasil wawancara yang dilakukan dengan Ketua Program Studi Pariwisata Universitas Negeri Gorontalo menyatakan bahwa, kendala yang dihadapi dalam proses pengembangan desa wisata seringkali datang dari masyarakatnya. Masyarakat belum siap dengan adanya keterbukaan dan kunjungan 
secara masif. Di samping itu kapasitas dan kapabilitas masyarakat masih rendah dimana mereka juga masih sangat terbatas dalam hal komunikasi terutama dengan wisatawan asing.

Adapun yang menjadi keunggulan pada warga Desa Olele adalah masyarakat yang telah sadar akan pentingnya kelestarian lingkungan. Hal ini menurut KaProdi Pariwisata UNG merupakan unsur yang sangat penting. Banyak terjadi di beberapa destinasi wisata adalah, wisata yang mulai ramai oleh pengunjung sementara kesadaran masyarakat untuk melestarikan objek wisata masih minim. Sehingga dalam hal ini dialami kesulitan untuk menanamkan lagi kesadaran akan pelestarian lingkungan. Akibatnya objek wisata tidak dapat bertahan lama kelestariannya atau harus mendapat intervensi pemerintah maupun swasta dalam pengelolaannya.

Adapun di Olele sendiri, kesadaran masyarakat telah lebih dahulu terbangun sebelum Taman Laut Olele menjadi destinasi wisata yang ramai pengunjung. Hal ini tentunya berimplikasi positif dimana walaupun dibuka untuk umum, masyarakat sendiri yang akan berupaya untuk menjaga kelestarian lingkungan wisata disekitar mereka. Hal ini juga tentunya menjadi modal utama dalam pengembangan eduwisata bahari berbasis pemberdayaan masyarakat. Konsep ini menempatkan masyarakat sebagai aktor utama dalam pengembangan pariwisata. Untuk itu dengan tertanamnya kesadaran pada masyarakat, maka diharapkan mereka dapat menanamkan pula kepada wisatawan yang berkunjung.

Dalam konsep eduwisata, masayarakat memegang peran kunci. Untuk itu pelibatan penuh setiap elemen masyarakat diperlukan dalam rangka mengembangkan dan mengelola destinasi wisata. Di Desa Olele sendiri masih diperlukan pengembangan kapasitas warga sehingga mampu mengelola pariwisata dengan lebih maksimal. Menurut penjelasan Sekdes Olele bahwa, masyarakat telah beberapa kali mengikuti pelatihan yang terkait pengelolaan wisata baik dalam hal 
manajemen wisata maupun pelatihan pemandu wisata. Pelatihan ini ada yang diinisiasi oleh pemerintah dan adapula yang diselenggarakan oleh kampus sebagai kegiatan pengabdian kepada masyarakat. Namun walaupun demikian tetap diperlukan upaya berkelanjutan dalam peningkatan kapasitas masyarakat yang dituangkan dalam strategi pengembangan wisata Desa Olele.

\section{Kendala yang Dihadapi}

Pada dasarnya wisata yang ditawarkan oleh Taman Laut Olele masih kurang familiar di kalangan wisatawan lokal. Dimana pada umumnya wisata bahari yang paling mengemuka adalah pantai dengan pasir putihnya. Wisata bawah laut baik snorkling maupun diving belum begitu dikenal, terutama dikalangan wisatawan lokal, dan terlebih lagi karena diperlukan kemampuan khusus dan menghabiskan biaya yang cukup tinggi. Hal ini tentunya menjadi tantangan dalam pengembangan wisata, dimana setiap elemen harus bekerjasama dalam pengembangan sektor wisata.

Terlebih lagi wisatawan yang datang ke Gorontalo sebagian besar tidak menjadikan Gorontalo sebagai destinasi utama melainkan sebagai tempat transit. Tujuan utama mereka adalah wilayah Sulawesi Utara atau Pulau Togean yang berada di perairan Sulawesi Tengah. Hal ini tentunya menjadi tantangan sendiri bagi Provinsi Gorontalo untuk mengembangkan sektor pariwisata dalam rangka menarik minat wisatawan. Taman Laut Olele sendiri pada dasarnya telah memiliki potensi tersebut sehingga diperlukan upaya sinergis dari semua pihak dalam hal pengembangan kawasannya.

Dalam hal pengembangan sektor wisata sendiri, diakui bahwa tidak mudah untuk memberikan layanan wisata yang diinginkan oleh para wisatawan, dimana wisatawan pada dasarnya mencari destinasi wisata yang tidak hanya menawarkan keindahan tetapi juga mampu memberikan kenyamanan. Dalam hal ini Desa Olele sendiri masih terkendala dalam banyak aspek. Dalam hal pembangunan 
insfrastruktur misalnya. Jalan masuk ke Desa Olele belum sepenuhnya layak dan masih banyak yang berlubang. Belum lagi terkait dengan penginapan. Wisatawan yang berkunjung ke Taman Laut Olele tidak mempunyai alternatif penginapan, sehingga kunjungan wisata sendiri bersifat jangka pendek. Adapun jika ingin membangun penginapan maka tentunya diperlukan investasi yang besar dan perizinan yang rumit.

Kendala yang dihadapi selanjutnya adalah tidak adanya sinkronisasi antara pengembangan Taman Laut Olele dan Desa Olele. Hal ini dikarenakan wisatawan sendiri lebih memilih jalur laut untuk sampai di Taman Laut Olele. Kondisi insfrastruktur jalan yang masih kurang memadai menyebabkan wisatawan berangkat dari pelabuhan kota Gorontalo menuju Taman Laut Olele. Kerena Desa Olele sendiri belum mampu menyediakan sarana akomodasi yang layak dan nyaman yang dibutuhkan oleh para wisatawan, sehingga wisatawan sendiri pada akhinya memilih untuk tinggal penginapan yang masih terpusat di Kota Gorontalo. Implikasi dari kondisi ini adalah masyarakat Desa Olele sendiri tidak mendapat manfaat dari pengembangan pariwisata.

Di samping itu, Desa Olele sendiri tidak memiliki nilai jual dan tidak memiliki atraksi wisata sehingga tidak mampu untuk menarik wisatawan untuk berkunjung. Hal ini juga disadari oleh pemerintah desa. Bahwa dalam hal menarik wisatawan desa harus memiliki daya tarik. Akan tetapi pengembangan desa sendiri masih terkendala biaya. Dibutuhkan pembiayaan besar dalam membangun dan mengembangkan desa menjadi sebuah desa wisata.

Warga Desa Olele sendiri telah menyediakan kapal kaca sebagai sarana wisata bawah laut, akan tetapi belum termanfaatkan secara maksimal. Menurut pengakuan seorang warga penyedia jasa, yang seringkali terjadi adalah buruknya proses tawar menawar dengan pemandu wisata. Sehingga keuntungan yang lebih besar diperoleh oleh pemandu wisata, dan warga desa hanya mampu mendapatkan 
imbalan seadanya. Padahal jika melihat sumber daya yang dimiliki, saat ini Desa Olele telah memiliki empat orang penyelam bersertifikat (master diving) yang dilengkapi dengan 16 tabung oksigen dan 9 set pakaian menyelam..

Promosi wisata sendiri belum dilakukan secara masif sehingga belum memaksimalkan potensi wisata yang dimiliki. Potensi wisata laut Olele pada kenyataannya belum dikenal secara meluas. Hal ini tentunya menjadi perhatian berbagai pihak dalam rangka promosi wisata. Strategi yang dapat dilakukan adalah dengan membuat website khusus yang menyediakan informasi terkait peariwisata bahari dan desa wisata Olele.

Kendala yang dihadapi dalam pengembangan Olele selanjutnya adalah masih tidak sinergisnya peran pemerintah baik dari pemerintah desa, kecamatan, kabupaten hingga provinsi. Masalah pendanaan menjadi masalah klasik yang dihadapi dalam pengembangan Desa Olele. Hal ini dikarenakan ketidakjelasan dalam pengelolaan Olele sebagai Pusat Konservasi. Diakui oleh sekretaris Desa Olele bahwa sangat sulit untuk meminta bantuan dana kepada pemerintah. Jika meminta kepada pemerintah Kabupaten Bone Bolango, maka akan dilalihkan ke Provinsi Gorontalo. Sementara ketika meminta bantuan ke Pemerintah Provinsi Gorontalo maka akan dikatakan bahwa Olele berada dalam wilayah hukum Kabupaten Bone Bolango. Untuk itu melalui inisiatif warga dan pemerintah Desa Olele, pembangunan mulai dilakukan dengan memanfaatkan dana desa terutama untuk pembangunan jalan utama menuju destinasi wisata.

\section{Strategi / Program Pengembangan}

Dari proses diskusi yang dilakukan dengan warga dan pihak-pihak terkait dirumuskan beberapa rekomedasi dalam rangka pengembangan wisata edukatif di Taman Laut Olele. Pertama, perlunya kejelasan dalam hal pengelolaan Taman Konservasi Laut Olele. Hal ini penting untuk menyusun rencana strategis pengembangan wisata berikut beban penganggarannya. Selanjutnya harus ada 
pembagian porsi dan tanggung jawab yang jelas antara peran pemerintah pusat, kabupaten hingga desa sehingga tidak terjadi tumpang tindih dan saling lempar tanggung jawab dalam hal pengelolaan dan pengembangan wisata.

Berdasarkan wawancara dengan Dinas Perikanan dan Kelautan Kab. Bone Bolango, menjelaskan bahwa jika merunut pada UU No 23 Tahun 2014 Tentang Pemerintah Daerah, maka Taman Laut Olele bukan lagi menjadi kewenangan kabupaten melainkan pemerintah provinsi. Pemerintah Kabupaten tidak dapat melakukan intervensi apa-apa karena terkait dengan tidak disediakannya dana pendukung. Akan tetapi pemerintah kabupaten tetap melakukan koordinasi dengan pemerintah dalam rangka perlindungan dan pengembangan kawasan konservasi Olele.

Program pariwisata yang baik adalah pariwisata yang memberdayakan masyarakat di sekitar lokasi wisata, sehingga majunya sektor pariwisata juga akan meningkatkan taraf hidup masyarakat. Rekomendasi kedua adalah menyusun kerangka strategis pengembangan Desa Wisata dengan menerapkan konsep eduwisata bahari. Hal utama yang upayakan dalam waktu dekat adalah dengan merancang pola manajeman berkelanjutan atas segala aktivitas wisata di Taman Laut Olele. Suatu destinasi atau Daerah destinasi sekarang ini bisa bisa mengatur akan daerahnya sendiri, mengelola daerahnya sendiri mulai dari penataan, pemeliharaan dan berdasarkan kearifan lokal sesuai bidangnya termasuk pariwisata. UU No.32 Tahun 2004 tentang otonomi daerah menyatakan bahwa daerah diberikan kebebasan dan kewenangan untuk menentukan arah pembangunan ekonominya masing-masing (Sudarmayasa 2019).

Pengelolaan ini tentunya dengan keterlibatan penuh dan aktif dari masyarakat Desa Olele. Pengelolaan sarana sarana wisata harus dilakukan oleh masyarakat. Terkait dengan hal tersebut maka masyarakat desa harus mendapat pendidikan dan pelatihan dalam rangka peningkatan kapasitas mereka. Salah satu 
yang penting adalah terkait pemandu wisata. Pemandu wisata dengan pengetahuan bahari, merupakan ujung tombak pengembangan eduwisata dimana pemandu wisata yang akan memberikan pemahaman kepada masyarakat terkait pentingnya pelestarian ekosistem perairan. Di samping itu diperlukan pengawas wisata yang merupakan tenaga ahli untuk mengawasi segala aktifitas di Taman Laut Olele. Pengawas wisata mempunyai kewenangan untuk memberikan sanksi kepada pengunjung yang melakukan pengrusakan lingkungan dan objek wisata. Selanjutnya adalah kelompok pelestari wisata, yang melakukan pengecekan berkala atas potensi bawah laut Olele.

Di samping peningkatan kapasitas warga desa dalam pelestarian lingkungan, diperlukan juga pelatihan terkait dengan pengembangan sektor ekonomi. Penting untuk memberikan pelatihan dan pembinaan keterampilan kepada warga khususnya pemuda desa. Pemuda akan diberi pengenalan mengenai usaha-usaha kreatif yang diikuti dengan pembentukan komunitas kreatif.

Pengembangan sumber daya manusia tentunya harus didukung dengan infrastuktur yang memadai. Diakui oleh Sekretaris Desa Olele bahwa infrastuktur di Desa Olele masih sangat minim untun menuju desa destinasi wisata. Dalam hal ini diperlukan perhatian penuh dari pemerintah dan sektor swasta dalam pengembangan infrastruktur. Dari hasil pengkajian yang dilakukan, program pemberdayaan masyarakat dilakukan dengan menyiapkan rumah tinggal (homestay) bagi wisatawan. Model ini dinggap cukup tepat dimana tidak diperlukan investasi besar, dan mampu melibatkan masyarakat secara langsung dalam pengelolaan pariwisata sehingga dengan sendirinya mampu menggerakkan perekonomian desa.

Penelitian mengenai usaha pondok wisata sebagai pendukung pariwisata berbasis masyarakat pernah dilakukan Arida Nyoman Sukma di Desa Wisata Ubud. Dari hasil penelitian menjelaskan bahwa pondok wisata merupakan solusi ideal bagi desa wisata untuk melibatkan masyarakat setempat (pariwisata berbasis masyarakat). 
Dalam bisnis industri pariwisata terutama usaha akomodasi pariwisata, yaitu usaha pondok wisata menawarkan harga yang murah dan dapat terjangkau sekaligus juga dapat meningkatkan tingkat pendapatan keluarga/masyarakat karena dapat menjadi pendapatan tambahan bagi masyarakat/keluarga. Dalam pengelolaan usaha pondok wisata/homestay, setelah dilakukan identifikasi, klasifikasi dan analisis terhadap berbagai informasi yang diperoleh maka suatu pondok wisata yang baik seharusnya terdapat fasilitas utama, fasilitas pendukung dan pelayanan pondok wisata (Arida 2018).

Wisatawan tidak lagi perlu mencari penginapan di wilayah Kota Gorontalo, akan tetapi dapat memanfaatkan rumah-rumah warga. Di sisi lain metode ini dengan sendirinya akan mampu meningkatkan pendapatan dan pengetahuan masyaraat dari proses interaksi dengan wisatawan baik lokal maupun internasional. Sebagian wisatawan juga merupakan wisatawan backpacker dengan pengeluaran yang minim. Hal ini tentunya menjadi peluang bagi Desa Olele untuk mengembangkan desa wisata berbasis Homestay. Dimana akomodasi murah dan nyaman dapat ditawarkan kepada wisatawan. Di sisi lain, metode ini tentunya akan lebih memberdayakan masyarakat. Dimana masyarakat akan berinterkasi secara langsung dengan wisatawan dan berpartisipasi dalam pengembangan desa wisata.

Untuk menarik wisatawan juga diperlukan dalam pengembangan dan pembenahan. Salah satunya adalah peremajaan rumah-rumah warga meliputi perbaikan sanitasi. Salah satu strategi yang dapat ditempuh adalah dengan pewarnaan pagar rumah, penataan lapangan parkir dan penyediaan tempat sampah. Dalam rangka pengembangan sektor ekokomi diperlukan stimulasi berupa pembangunan pusat wisata seperti coffee shop atau pusat cenderamata khas Olele. Disamping mengembangkan perekonomian, metode ini menjadi sarana promosi produk khas daerah. 
Pengembangan sektor wisata tentunya bukan hal mudah. Pengembangan diperlukan dalam hal pengelolaan, sumber daya manusia dan infrastruktur. Untuk itu diperlukan partisipasi dan kolaborasi dari semua pihak baik pemerintah, swasta terutama masyarakat dalam membangun pariwisata bahari berbasis pemberdayaan masyarakat yang berkelanjutan.

\section{Kesimpulan}

Taman Laut Olele memiliki potensi yang sangat besar jika dilihat dari kekayaan biota laut yang dimiliki. Akan tetapi pengelolaan yang belum maksimal menjadikan Taman Olele tidak memberi manfaat bagi masyarakat Desa Olele pada khususnya. Masih rendahnya pengetahuan masyarakat terkait pengelolaan sektor wisata dan masih minimnya insftrastruktur pendukung menjadi hambatan dalam pengembangan Taman Laut Olele.

Beberapa strategi sepatutnya mulai dikembangkan dengan kolaborasi antara masyarakat, pemerintah dan swasta dimana konsep eduwisata bahari menjadi pilihan yang tepat. Di satu sisi model ini akan berupaya melestarikan lingkungan dan kekayaan alam Taman laut Olele. Dan sisi lain dapat memberikan keuntungan ekonomis dengan pelibatan masyarakat secara penuh dalam pengelolaan sektor wisata.

\section{Daftar Pustaka}

Agfianto, Tomi. 2019. “Dampak Ekonomi Pengembangan Community Based Tourism Terhadap Masyarakat Lokal di Kabupaten Malang (Studi Kasus Destinasi Wisata Cafe Sawah Pujon Kidul ) Pendahuluan." Jurnal Master Pariwisata (JUMPA) 05(2): 259-82.

Arida, Nyoman Sukma. 2018. "Usaha pondok wisata sebagai pendukung pariwisata budaya berkelanjutan di desa wisata ubud." JUMPA - Jurnal Master Pariwisata 05(01): 227-40. 
Benteng, Beby Sintia Dewi. 2013. "Pengelolaan Kawasan Pesisir Berbasis Masyarakat Di Taman Konservasi Laut Olele Kecamatan Kabila Bone Kabupaten Bone Bolango Provinsi Gorontalo." Disertasi.

Hall, Colin Michael. 2017. "Trends in ocean and coastal tourism: The end of the last frontier?" 5691(December 2001): 0-18.

Herdiana, Dian. "Peran Masyarakat dalam Pengembangan Desa Wisata Berbasis Masyarakat." JUMPA - Jurnal Master Pariwisata 6(1): 63-86.

Kamuli, Sukarman. 2018. TRANSISI PEMBANGUNAN DI PESISIR Organisasi, Kemitraan, dan Partisipasi Di Gorontalo Utara. ed. Basri Amin. Jakarta Timur: Pustaka Indonesia Press.

RIPDA. 2015. "Rencana Induk Pengembangan Pariwisata Daerah Kab Bone Bolango."

Sastrayuda, Gumelar. 2010. “Konsep Pemberdayaan Masyarakat Berbasis Pariwisata - Community Based Tourism." : 1-17.

Savitri, Ananditya, dan Novi Utami. 2018. "Potensi Pengembangan Promosi Eduwisata Teh Sarongge Dalam Penerapan Value Green Tourism Di Desa Sarongge , Pacet Jawa Barat - Potential For The Development Of The Promotion Sarongge Tea In The Application Of The Green Tourism Value In Saronnge Village , P." 4(1): 88-94.

Sidiq, Ade Jafar, dan Risna Resnawaty. 2017. “Pengembangan Desa Wisata Berbasis Partisipasi Masyarakat Lokal di Desa Wisata Linggarjati Kuningan, Jawa Barat." Prosiding KS: Riset dan PKM 4(1).

Sudarmayasa, I Wayan. 2019. “Dampak Keberadaan Sektor Pariwisata Terhadap Peningkatan Faktor Sosial Ekonomi Masyarakat Kampung Tenun Samarinda di Kota Samarinda Kalimantan Timur." Jurnal Master Pariwisata (JUMPA) 05(2): 283-95.

Suyanto, Edy, Fx Wardiyono, Tri Wuryaningsih, dan Tri Rini Widyastuti. 2018. "Model Kebijakan Pengelolaan Ekowisata Hutan Mangrove Berbasis Partisipasi Masyarakat Dan Potensi Lokal Kampung Laut Segara Anakan." Prosiding Seminar Nasional dan Call for Papers "Pengembangan Sumber Daya Perdesaan dan Kearifan Lokal Berkelanjutan VIII (November): 8-16.

Wawancara dengan Sekretaris Desa Olele dan Tokoh Masyarakat Desa Olele pada 16 Juni 2019

Wawancara dengan Ketua Program Studi Pariwisata, Universitas Negeri Gorontalo, pada 17 Juni 2019. 
Eduwisata Bahari Berbasis Pemberdayaan Masyarakat dalam Pengembangan Taman Laut Olele...

Wawancara dengan Kepala Dinas Pariwisata dan Ekonomi Kreatif Kab. Bone Bolango, pada 17 Juni 2019.

\section{PROFIL PENULIS}

Atika Puspita Marzaman, staf pengajar di Program Studi Ilmu Pemerintahan, Universitas Gorontalo. Alumnus (S1) Program studi Ilmu Hubungan Internasional Universitas Hasanuddin dan mendapatkan gelas master untuk bidang ilmu yang sama di Universitas Gadjah Mada.

Ayub Usman Rasyid, staf pengajar di Program Studi Ilmu Manajemen, Universitas Gorontalo. Alumnus (S2) Universitas Muslim Indonesia. Saat ini menjabat sebagai Kepala Lembaga Penjaminan Mutu Universitas Gorontalo. 